\title{
Bacterial Number, Heterotrophy and Extra Cellular Enzyme Activity in the Sea Water of Alexandria Harbour, Egypt
}

\author{
Eman I. Siam \\ Assistant Professor in Marine Environmental Protection Programme \\ Arab Academy for Science and Technology and Maritime Transport
}

\begin{abstract}
To study the structure and function of bacterial population in Alexandria harbour which is located between $29^{\circ} 50^{\prime}-29^{\circ} 53^{\prime}$ longitude E and $13^{\circ} 9^{\prime}-31^{\circ} 12^{\prime}$ latitude N. Eight sampling station were chosen. Samples were collected from surface and bottom sea water during 2001-2002.

The number of total bacterial in sea water was between $2.3 \times 10^{4}$ cells / $\mathrm{ml}$ and 1.4 $\mathrm{x} 10^{5}$ cells / $\mathrm{ml}$ and the total saprophytic bacteria was significantly law with regard to the total bacterial number. Turnover times of glucose and leucine were extremely variable depending on the sampling station and the water depth.

In deep sea water the enzyme activity of a $\alpha$-glycosidase $\mathrm{N}$-acetyl, $\beta$ glucosaminidase and amino peptidase of the slow growing bacterial population were higher then those of the fast growing bacterial population, B- glycosidase activities, however, were higher in the fast6 growing bacterial population.
\end{abstract}

\section{Introduction}

Bacterial heterotrophy was consid ered negligible in sea water, but now, it is starting to appear an important pathway of secondary food chain production. Detrital material particu larly that are derived from tiny crustaceans appears to enter the food chain at different trophic levels (Vincent 1998). Bacteria in seawater exhibit a number of interesting prope rties and additionally play an essential role in the cycling of nutrient (Nessim 1990). The Mediterranean Sea is an area of outstanding scientific interest and the bacterial load in its water varies according to factors like sewage dispo sal and maritime activities.

From this view, this study was carried out to show the structure and function of bacterial population in the Egyptian Mediterranean waters.

Area of Investigation

The western harbour lies between $29^{\circ} 50^{\prime}-29^{\circ} 53^{\prime}$ longitude $\mathrm{E}$ and $13^{\circ} 9^{\prime}$
- $31^{\circ} 12^{\prime}$ latitude $\mathrm{N}$ and occupies an area of about 1862 ha., the harbour is shallow (water max. depth of about 16 m.) and opens to the sea by a narrow canal called "El-Boughaz" (Figure 1).

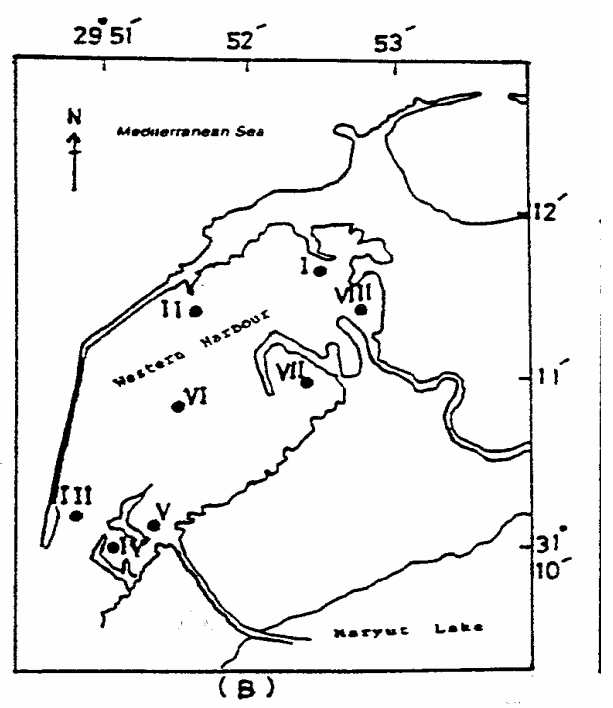

Figure (1): Western harbour of Alexandria 


\section{E.E.Siam}

In addition to the pollution which can result from different shipping activities, e.g. cargo, tankers and passé ngers ships the marine environment and biota of the harbour could also be subjected to other different types of pollutants, i.e. industrial, agricultural and domestic effluents from the following sources:

1. El-Noubaria Canal, which passes across lake Maryout discharges 9000 cubic meters daily of fresh waters, loaded with suspended subs -tances (Shriadah \& Taijel 1992);

2. Several outfalls, at El-mahmoudia Canal which introduces remarkable amounts of untreated domestic wastes; and

3. El-Mex pumping station which discharges 6 million cubic meters daily of polluted brackish waters (Abdel Aziz 1997).

\section{Materials and Methods}

Surface and bottom sea water samples were collected during day time at one meter depth and at (about ten meters depth) water layer from eight stations in the western harbour (Figure 1) seasonally during 2001-2002 in sterile two liter screw capped bottles.

To estimate total bacterial cell number's epifluorescent microscopic method was used (Zimmer Mann 1977, Pomroy 1984).

To enumerate total saprophytic bacterial number, the membrane filter method (pore size: $0.45 \mathrm{~m}^{3}$ ) and plate count method with Zobell 2216 E Agar meridian was used.
Zobell Agar plates were incubated at $8^{\circ} \mathrm{C}$ for 15 days. The extra cellular enzyme activities of $\mathrm{X}$ and $\mathrm{B}$ glucosidease, $\mathrm{N}$-acetyl, $\beta$-gluco-sami nidase and amino peptidase were determinated by the method described by KIM and Hoppe (1986). For the assessment of microbial activity, turnover time was measured by the method described by Gocke, et.al (1990) using ${ }^{14} \mathrm{C}$-glucose and $\mathrm{C}^{14}$ leucine as substrates.

\section{Results \& Discussion}

Table (1) and Figure (1) show the number of total bacterial and total saprophytes in each station of Alexandria western harbour at both surface and bottom seawater. The num ber of total bacterial cells varied from $2.3 \times 10^{4}$ cells $/ \mathrm{ml}$ to $1.4 \times 10^{5}$ cells $/ \mathrm{ml}$. In most stations the total cell number in the surface water layer was higher than that in the near bottom layer. This difference may be due to the high amount of nutrients in the surface sea water which support bacterial growth

The total cell number obtained in the present investigation was found to be similar to that reported by Hanson et.al (1993) for the Antarctic waters with values ranging between $1 \times 10^{4}$ and $2 \times 10^{5}$ cells $/ \mathrm{ml}$.

Table (1) and Figure (2) show the fluctuation of total saprophytic bacteria number between $0.5 \times 10^{2}$ and $1.5 \times 10^{2}$ CFU/l during the sampling period. These counts are similar to that reported for the eastern harbour in 1995 by Siam (1998). When compared with the total bacterial number the saprophyte number was extremely low. 
Table (1): Number of total and saprophyte bacteria in Mediterranean Sea Water collected from eight stations of western harbour in Alexandria

\begin{tabular}{|c|c|c|c|}
\hline $\begin{array}{c}\text { Station } \\
\text { No. }\end{array}$ & $\begin{array}{c}\text { Sampling } \\
\text { Depth }\end{array}$ & $\begin{array}{c}\text { Total bacteria number } \times 10^{4} \\
\text { cells } / \mathrm{ml}\end{array}$ & $\begin{array}{c}\text { Total saprophyte bacteria number } \\
\mathbf{1} 10^{2} \text { CFU/I }\end{array}$ \\
\hline 1 & S & $13.6-$ & 31 \\
& B & 8.3 & 11 \\
\hline 2 & S & 7.5 & 24 \\
& B & 11.3 & 15 \\
\hline 3 & S & 6.1 & $0.5-$ \\
\hline 4 & B & $2.3-$ & 24 \\
& S & 8.0 & 8.5 \\
\hline 5 & S & 5.8 & 29 \\
& B & 5.6 & 21 \\
\hline 6 & S & 6.6 & 11 \\
& B & 9.8 & 30 \\
\hline 7 & S & 8.2 & 3.5 \\
\hline 8 & B & 7.0 & 25 \\
& S & 4.9 & 30 \\
\hline \multicolumn{2}{|c|}{ S: surface water sample } \\
\hline
\end{tabular}

B: bottom water sample

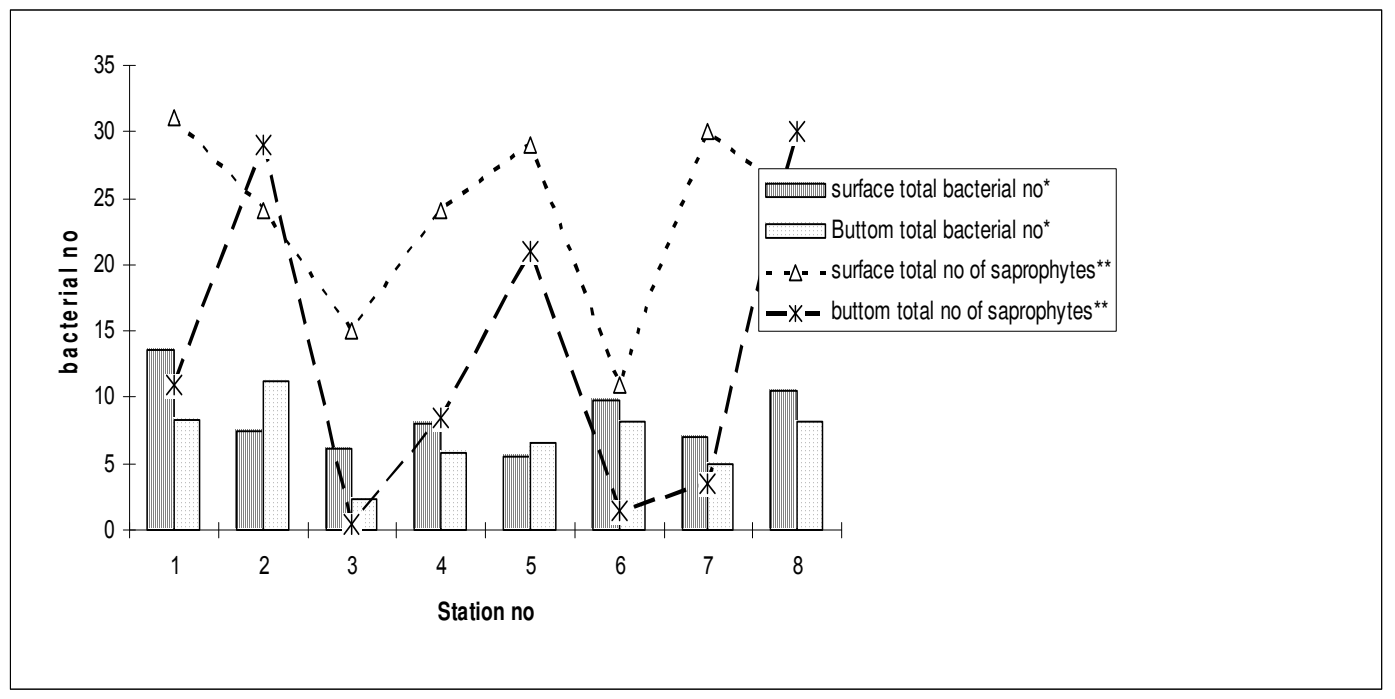

Figure (2)

The turnover times for glucose and leucine in seawater samples from the Alexandria harbour are given in table (2). These values were in the range of $41.3-2093.7$ hours and $55.8-979.9$ hours, respectively and varied depend ing on the sampling station and depth.

Figure (3) shows that the turnover time of glucose in surface sea water in station 4, 6, 7 and 8 were higher then the turnover times of the near bottom water samples, it also shows that the turnover times of leucine were signify cantly shorter than those of glucose indication that leucine could be taken up and remineralized faster than glucose in the water column of the Alexandria western harbour. 


\section{E.E.Siam}

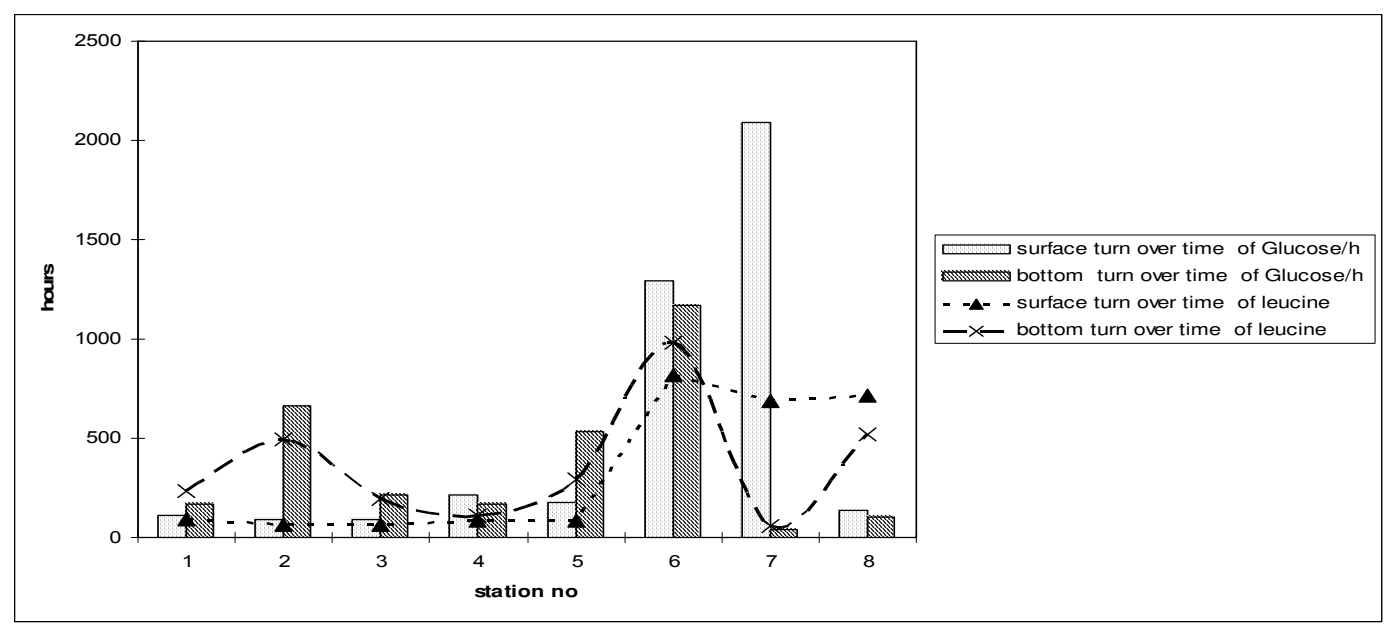

Table (2): Turnover time of glucose and leucine in seawater samples from the Alexandria western harbour

\begin{tabular}{|c|c|c|c|}
\hline Station No. & Sampling Depth & Glucose $(\mathrm{h})$ & Leucine $(\mathrm{h})$ \\
\hline 1 & S & 112.1 & 92.3 \\
& B & 170.1 & 235.5 \\
\hline 2 & S & 88.9 & 62.3 \\
& B & 664.6 & 495.1 \\
\hline 3 & S & 90.7 & 62.3 \\
& B & 212.1 & 192.8 \\
\hline 4 & S & 214.5 & 82.6 \\
& B & 167.6 & 110.2 \\
\hline 5 & S & 178.2 & 84.2 \\
& B & 530.9 & 294.6 \\
\hline 6 & S & 1291.8 & 816.6 \\
& B & 1168.2 & 979.9 \\
\hline 7 & S & 2093.7 & 687.7 \\
& B & 41.3 & 55.8 \\
\hline 8 & S & 138.2 & 713 \\
& B & 105.6 & 522 \\
\hline
\end{tabular}

Water temperature is not likely to play an important role for the spatial distribution of heterotrophic bacteria potential as long as it remains unflactu ated in Alexandria western harbour (Tayel, 1997). Under this circumstance, the effect of total bacterial cell number and its metabolic activity (active or dormant) together with the concentrati on of organic nutrients on total heterot rophic potential may become dominant. Table (3) shows the percentage of colonies which specified enzyme activ ities to total colonies during different incubation periods of water samples collected at eight stations in Alexandria western harbour. The bacteria forming colonies within 5 days were classified as the fast growing population and those growing to colonies after 6 days of inc ubation as the slow growing population.

The enzyme activities of $\alpha$-glyco sidase, $\mathrm{N}$-acetyl, $\beta$-glucosaminidase and aminopeptidase in the fast growing population were higher compared with those in the slow growing population.

In case of $\beta$-glycosidase activities, however, a reverse result was obtained with an implication that the slow growing bacterial population can play a major role for cellulose decomposition in the deep water environment of Alexandria western harbour. 
Table (3): Percentage of positive bacterial colonies showing enzyme activities to total colonies during different incubation periods from near bottom (about10 meters depth) seawater samples in the western harbour

\begin{tabular}{|c|c|c|c|c|c|c|c|c|c|c|c|c|}
\hline \multirow[t]{2}{*}{ Station } & \multicolumn{3}{|c|}{ a-glucosidase } & \multicolumn{3}{|c|}{$\beta$-glucosidase } & \multicolumn{3}{|c|}{$\begin{array}{c}\mathrm{N} \text {-acetyl, } \beta \text { - } \\
\text { glucosaminidase }\end{array}$} & \multicolumn{3}{|c|}{ Aminopeptidase } \\
\hline & $\begin{array}{c}\text { Within } \\
0-5 \\
\text { days }\end{array}$ & $\begin{array}{c}\text { Within } \\
6-15 \\
\text { days }\end{array}$ & $\begin{array}{l}\text { Total } \\
\text { period }\end{array}$ & $\begin{array}{c}\text { Within } \\
0-5 \\
\text { days }\end{array}$ & $\begin{array}{c}\text { Within } \\
6-15 \\
\text { days }\end{array}$ & $\begin{array}{l}\text { Total } \\
\text { period }\end{array}$ & $\begin{array}{c}\text { Within } \\
0-5 \\
\text { days }\end{array}$ & $\begin{array}{c}\text { Within } \\
6-15 \\
\text { days }\end{array}$ & $\begin{array}{c}\text { Total } \\
\text { period }\end{array}$ & $\begin{array}{c}\text { Within } \\
0-5 \\
\text { days }\end{array}$ & $\begin{array}{c}\text { Within } \\
6-15 \\
\text { days }\end{array}$ & $\begin{array}{l}\text { Total } \\
\text { period }\end{array}$ \\
\hline 1 & 59 & 64 & 62 & 0 & 47 & 25 & 17 & 5 & 11 & 96 & 79 & 86 \\
\hline 2 & 96 & 50 & 78 & 0 & 25 & 7 & 0 & 0 & 0 & 100 & 63 & 90 \\
\hline 3 & 86 & 70 & 82 & 0 & 33 & 16 & 5 & 0 & 4 & 100 & 87 & 94 \\
\hline 4 & 71 & 63 & 69 & 0 & 30 & 8 & 0 & 0 & 0 & 100 & 7 & 93 \\
\hline 5 & 96 & 78 & 91 & 2 & 5 & 3 & 0 & 0 & 0 & 62 & 64 & 63 \\
\hline 6 & 100 & 0 & 98 & 0 & 0 & 0 & 5 & 0 & 4 & 75 & 0 & 67 \\
\hline 7 & 21 & 10 & 17 & 2 & 7 & 3 & 68 & 32 & 56 & 76 & 50 & 66 \\
\hline 8 & 100 & 63 & 83 & 0 & 14 & 5 & 55 & 17 & 49 & 63 & 33 & 56 \\
\hline Average & 78.62 & 49.75 & 72.5 & 0.5 & 20.13 & 8.4 & 18.8 & 6.75 & 15.5 & 84 & 56.6 & 76.9 \\
\hline
\end{tabular}

\section{References}

1. Shriadah M.M.A and Tayel F.T (1992), Environmental condition of the western harbour of Alexandria I. physico-Chemical characteristics. The Bulletin of the High Institute of public health, Alexandria - Egypt 213-28.

2. Abdel-Aziz, N.E.M (1997) Zooplankton production along Egyptian Mediterranean Coast at Alexandria, with special references to life history of one copcpode species Ph.D thesis Faculty of Science, Mansoura University, $384 \mathrm{pp}$.

3. Gocke, K., A.. Heinanen,O.Kirstin, M.maciejowaska G. Panov, and A. Tsiban (1990) Microorganisms In: Second periodic Assessment of the state of the marine environment of Baltic sea 1984-1988. Background document, Baltic sea environment proceeding No. 35B, 303-329, Baltic marine environment protection commis -sion, Helsinki commission 1990.

4. Nessiam, R.B. (1990). Nutrient levels and chrophylla in Alexandria coastal waters, Bull. Instit. Oceanogr. Fish. Egypt, 17 (1): 129-140.

5. Vincent, W.F. (1986). Microbial ecosystem of Antarctica, Cambridge University press $15,365-375$.

6. Pomroy, A. J. (1984). Direct counting of bacteria preserved with Lugol-iodine solution. Appl. Environ. Microbial 47, 1191-1192.

7. Zimmermann, R. (1977). Estimation of bacterial number and biomass by epifluorescence microscopy and scanning electron microscopy. In G. Rhein-heimer (ed.) Microbial ecology of brackish water environment, springer- verlag, Berlin, 103-120.

8. Kim, S. J. and H., G. Hoppe, (1986). Microbial extracellular enzyme detection on agar plates by means of fluorogenic methylunbelliferyl substra tes. Deuxieme collogue international de bacteriologie marine. CNRs, Brest, Actes de collogues 3, 175-183.

9. Hanson, R.B., H. K. Lowery, D. Shafer, R. Sorocco and D.H. Pope, (1993). Microbes in cold water: vertical pattern of substrates uptake, produc tivity and biomass. Polar biology 2, 179-188.

10. Siam. E.E. (1998). A Synoptic Survey on Number of bacteria and Biomass in relation to physico-chemical parameters in Eastern harbour of Alexandria Egypt. Bull. Nat. Inst. Of Oceanogr. \& Fish., A.R.E 1998, vol. 24: 103-117.

11. Tayel. F.T.R. (1997).A comparative study on the state of Aromatic Hydrocarbon pollution In Abu Qir bay and the western harbour of Alexandria. Bull. Nat.Inst Of Oceanogr. \& Fish., A.R.E.1997,vol 23:155-165. 


\section{E.E.Siam}

\section{تقييم عملية زيادة خصوبة مياه خليج المكس بالإسكندرية باستخذام نموذج تجريبي للتقييم البيئي

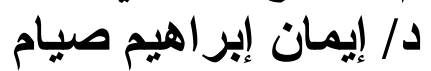

أستاذ مساعد بيرنامج حماية البيئة ـ الأكاديمية العربية للعلوم و التكنولوجيا

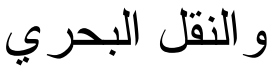

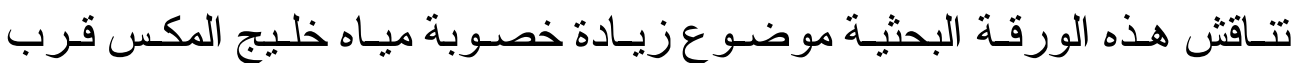

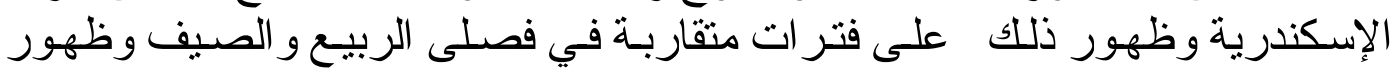
السوطيات السامة التي تسبب كثير المن التلوثر

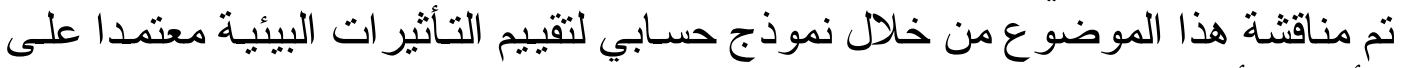

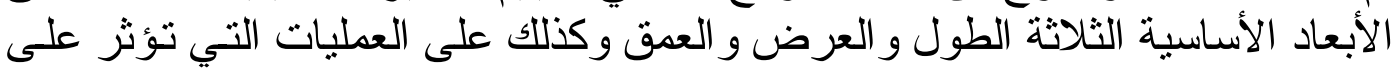

وييدأ بقياس العو امل البيئية ثم تأثير العو امل الخارجية ويستخدم كذلك لتحفيز الكتلة

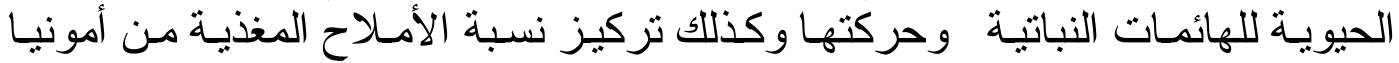

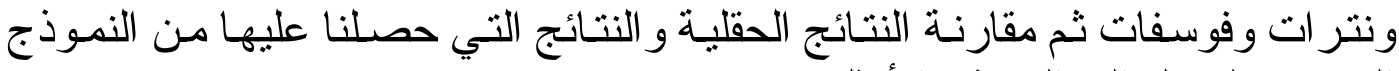
التجريبي لنصل إلى النموذج الأمتل.

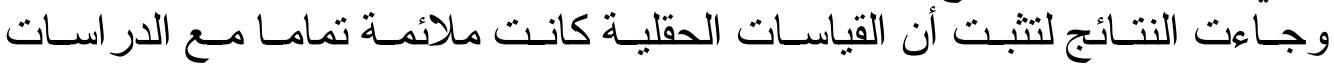

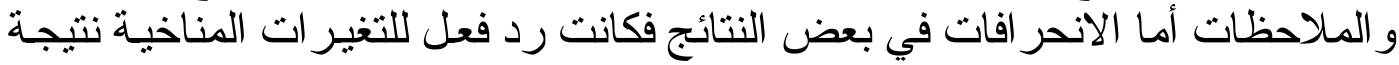

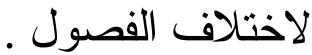
و أظهرت النتائج أيضا أن توزيع الهائسات النباتيـة كان ملازما لتركيز الكلوروفيل الحيوي(أ) المحسوب بو اسطة النموذج القياسي. و أوضحت النتائج ضرورة السيطرة على الملوثات الخارجية التي تصب في في خليج

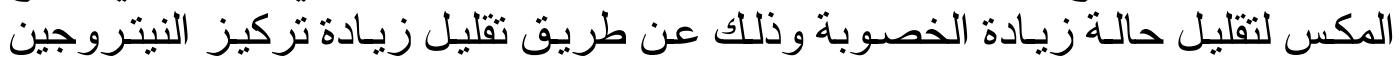
و الفسفور في مياه الخليج. 